\title{
Vegetation Composition in a Post-Fire Successional Gradient of Pinus halepensis Forests in Attica, Greece*
}

\author{
Dimitris Kazanis and Margarita Arianoutsou ${ }^{1}$ \\ ${ }^{1}$ Department of Ecology and Systematics, Faculty of Biology, University of Athens, Athens 15784, Greece \\ Tel.: 301 7284352, Fax: 301 7243325; e-mail: marianou@atlas.uoa.gr
}

\begin{abstract}
The vegetation composition of a post-fire succession in Aleppo pine forests of Attica, Greece, was studied by a synchronic method. The sites form a post-fire chronosequence and have typical Mediterranean climate. Data on the flora of the burned sites, growth and life forms of the various plant taxa, as well as on vegetation structure are provided. The burned ecosystems recovered quite rapidly. During the first four years of the post-fire succession, herbaceous taxa dominate the flora of the forests, peaking at the second year. After 15 years little change in the vegetation was observed. The richest family in terms of the number of taxa was the Leguminosae, especially in the two first years of succession. Most of these taxa were herbaceous. The relative contribution of legumes to the flora after two years is gradually restricted.
\end{abstract}

Keywords: Life forms; Regeneration mode; Pinus halepensis forests; legumes; Greece

\section{Introduction}

Fire is known to be one of the primary factors affecting vegetation of Mediterranean - climate ecosystems (Naveh 1967, 1973). The flora of these ecosystems has evolved certain mechanisms in order to persist in a regime of stand - replacing fires (Naveh 1973, Rundel 1981, Arianoutsou-Faraggitaki and Margaris 1981a). Fire - resistant bark, enhanced seed germination and vegetative growth from root crowns are some of these mechanisms.

One of the main ecosystem types in Greece is that of the Mediterranean pine forests. In the mainland of Greece the dominant pine tree is Pinus halepensis Mill. (Aleppo pine), while on the islands of the East Aegean Sea and on Crete Aleppo pine is replaced by Pinus brutia Ter, (East Mediterranean pine). Together they cover $8.7 \%$ of the forcsted area of Greece (Ministry of Agriculture 1992).

* Originally presented at the 2nd International Conference on Forest Fire Research. November 21-24, 1994, Coimbra, Portugal.
About $24.1 \%$ of the area burned each year during the dry summer in Greece is Aleppo and East Mediterranean pine forests (Kailidis 1992). Between 1965 and 1989. 122015 ha of Pinus halepensis forests burned, which is 33\% of the total Aleppo pine forests in Greece (Kailidis 1992). The situation becomes more severe in the forests neighbouring urban areas and tourist resorts, as these forests are subjected to increasing pressure for land-use changes, especially when bumed. In order to contribute towards accumulation of the knowledge needed to apply ecologically sound post-fire management plans, we undertook a study on post-fire succession of Mediterranean pine forests. This paper reports on the vegetation composition in a post-fire succesional gradient of Aleppo pine forests in Attica, where these forests constitute approximately $40 \%$ of its forested cover and $18 \%$ of the overall Pinus halepensis cover in Greece (Ministry of Agriculture 1992).

\section{Materials and Methods}

Seven study sites were selected for sampling on hillsides around Athens. Times since the last burn were 1,2, $3,4,11,15$ and more than 30 years. We tried to select sites that were as similar as possible, but this was difficult because of high variability in bedrock types. As long as the dominant woody flora was identical and the degree of human interference with the ecosystem was similar the sites were considered for sampling. All sites have typical Mediterranean climate, that is mild, subhumid winters and iong, dry hot summers. Sites descriptions are presented in Table 1.

The study was conducted from October 1992 to June 1993. Plant regeneration mode and life form were recorded at the one-year burned site, but information about these vital attributes is also provided for the later stages. A plant taxon can be a seeder, a resprouter or a facultative resprouter according to its regeneration mode, while it can be classified as a phanerophyte, a chamaephyte, an hemicryptophyte, a geophyte or a therophyte in the 
Table 1.The characteristics of the study sites

\begin{tabular}{ccccc}
\hline $\begin{array}{c}\text { Stand Age } \\
\text { (yr) }\end{array}$ & Date of Fire & Locality & $\begin{array}{c}\text { Bedrock } \\
\text { Material }\end{array}$ & $\begin{array}{c}\text { Altitude } \\
(\mathrm{m})\end{array}$ \\
\hline 1 & Sep 92 & KAPANDRIT & $\begin{array}{c}\text { Tertiary } \\
\text { deposits }\end{array}$ & 350 \\
& Sep 91 & AVLONA & Limestone & 400 \\
2 & Aug 90 & STAMATA & Schists & 350 \\
3 & Jul 89 & FYLI & Limestone & 400 \\
4 & Aug 82 & DIONYSOS & Schists & 450 \\
11 & Jul 78 & PIKERMI & $\begin{array}{c}\text { Tertiary } \\
\text { deposits }\end{array}$ & 200 \\
15 & before & PIKERMI & Tertiary & 200 \\
& 1960 & & deposits & \\
\hline
\end{tabular}

Raunkiaer life form system. Raunkiaer (1934) defined the life form of a plant in terms of the position and degree of protection of its perennating bud relative to the ground surface $(>25 \mathrm{~cm}$ for the woody phanerophytes; close to the ground but less than $25 \mathrm{~cm}$ from the surface for the chamaephytes - which are also woody perennials; renewal buds at the surface of the ground for the hemicryptophytes - many graminaceous and herbaceous plants; beneath the soil surface for the geophytes; and as an embryo in buried seeds for the therophytes). This system provides a means of classifying flora which focuses on the natural selection of vegetative organs in response to environmental pressures and the ultimate morphological adaptations that enable the plant to survive unfavourable conditions.

To describe the vegetation composition we used linetransects, which are especially advantageous and efficient for use in studies of succession in transition zones (Brower et al. 1990). In every stand we randomly located three $100-\mathrm{m}$ line transects, keeping a minimum distance of 50 meters between them. On a monthly basis, we recorded occurence of all plant species that were intercepted by a one-meter-long line (vertical plane) crossing the main transect at a right angle at one meter intervals.

The sites were grouped in clusters with the aid of an hierarchical agglomerative method provided by the PRIMER statistical program (version 3.1, Clarke and Warwick 1994). This method takes a Bray-Curtis similarity matrix as its starting point and successively fuses the samples into groups and the groups into larger clusters, starting with the highest mutual similarity then gradually lowering the similarity level at which groups are formed. The result of this hierarchical clustering is a dendrogram, where $\mathrm{x}$ axis is the full set of sites and the $\mathrm{y}$ axis is defining a similarity level at which two samples are considered to have fused. Note that the Bray-Curtis similarity matrix is formed by coefficients calculated on species presence/absence (1/0) data, which practically is identical to Sorensen similarity coefficient (Brower et al. 1989, Clarke and Warwick 1994).

$$
\text { Sorensen Similarity Coefficient: } \quad C C_{3}=\frac{2 c}{S_{1}+S_{2}}
$$

where $c=$ the number of species common to both sites, $S_{1}$ and $S_{2}$ are the numbers of species in sites 1 and 2 respectively.

Plant nomenclature follows Med - Checklist (Greuter et al 1984-1989) and Flora Europaea (Tutin et al 19681980) for the families not included in the published volumes of Med - Checklist.

\section{Results}

Plant taxa found along the line transects at each study site are given in Table 2. Regeneration mode and life forms of these taxa are also shown in Table 2. During the first three years after the fire the richest family, in terms of number of taxa, was the legume farmily (Leguminosae). In the more mature stands of the post-fire chronosequence other families, such as Compositae, Gramineae and Liliaceae, appeared to have rather more representatives than the rest of the families.

The richest flora was observed on the two-year-old site, while the smallest number was noted on the elevenyear-old site (Figure 1).

As far as it concerns the various life forms represented in the plants recorded, it is evident that therophytes were important in the early successional stages, while phanerophytes and chamaephytes were dominant in later stages (Figure 2).

The regeneration mode of each plant taxon is closely related to its life form. All therophytes are exclusively seeders and the geophytes are exclusively resprouters. Plants in the other life forms appear to be facultative resprouters (Table 3 ).

Cluster analysis on the data collected from all study sites indicated that sites were primarily grouped in regard to their successional stage, and that bedrock material had little but not overwhelming influence on this grouping (Figure 3). Two major groups were distinguished. The first was formed by the two sites of the very early post-fire successional stages on tertiary deposits and limestone respectively, while the second consisted of ail the other sites. The second group was divided in two subgroups: that of the third and fourth post fire year (schists and limestone respectively), and that of the 11-year, 15year and mature sites (schists and tertiary deposits respectively).

\section{Discussion}

Since 1934, when Raunkiaer introduced his life form system, it has met with a great deal of application in all the fields of terrestrial ecology. The system can be successfully applied in the study of post-fire succession, as a 
Table 2. List of plant taxa observed in all study sites. The classification of the life form (LF) follow's the Raunkiaer ssystem (Ph: Phanerophytes, Ch: Chamaephytes, G: Geophytes, H: Hemicryptophytes, Th: Therophytes). According to their regeneration mode (RM) plants are classified as obligate seeders(OS), obligate resprouters (OR) or facultative seeders (FS).

\begin{tabular}{|c|c|c|c|c|c|c|c|c|c|}
\hline \multirow[b]{2}{*}{ TAXA } & \multicolumn{7}{|c|}{ Post-Fire Years } & \multirow[b]{2}{*}{$\mathbf{L F}$} & \multirow[b]{2}{*}{$\mathbf{R M}$} \\
\hline & 1 & 2 & $\mathbf{3}$ & 4 & 11 & $\mathbf{1 5}$ & $>\mathbf{3 0}$ & & \\
\hline $\begin{array}{l}\text { 1.PINACEAE } \\
\text { Pinus halepensis } \\
\text { 2.FAGACEAE }\end{array}$ & & & + & + & + & + & + & $\mathrm{Ph}$ & OS \\
\hline Quercus pubescens & & & - & - & + & - & - & $\mathrm{Ph}$ & OR \\
\hline $\begin{array}{l}\text { Quercus coccifera } \\
\text { 3.CARYOPHYLLACEAE }\end{array}$ & & & + & + & + & + & + & $\mathrm{Ph}$ & OR \\
\hline Stellaria media & - & + & - & - & - & - & - & $\mathrm{Th}$ & OS \\
\hline Silene vulgaris & - & + & - & - & - & - & - & $\mathrm{H}$ & FS? \\
\hline $\begin{array}{l}\text { Silene colorata } \\
\text { 4.RANUNCULACEA }\end{array}$ & - & + & - & - & - & - & - & $\mathrm{Th}$ & OS \\
\hline Anemone blanda & & & + & - & - & - & - & $\mathrm{H}$ & OR \\
\hline $\begin{array}{l}\text { Clematis vitalba } \\
\text { 5.PAPAVERACEAE }\end{array}$ & & & - & - & - & - & - & $\mathrm{Ph}$ & OR \\
\hline Papaver rhoeas & - & + & - & - & - & - & - & $\mathrm{Th}$ & os \\
\hline $\begin{array}{l}\text { Fumaria schleicheri } \\
\text { 6.CRUCIFERAE }\end{array}$ & + & + & + & - & - & + & - & $\mathrm{Th}$ & OS \\
\hline Hirschfeldia incana & - & - & - & + & - & - & - & $\mathrm{Th}$ & OS \\
\hline Capsella bursa-pastoris & - & + & + & - & - & - & + & $\mathrm{Th}$ & OS \\
\hline $\begin{array}{l}\text { Biscutella didyma } \\
\text { 7.ROSACEAE }\end{array}$ & - & + & + & - & - & - & - & $\mathrm{Th}$ & OS \\
\hline $\begin{array}{l}\text { Sarcopoterium spinosum } \\
\text { 8.LEGUMINOSAE }\end{array}$ & & & - & + & + & + & - & $\mathrm{Ch}$ & FS \\
\hline Anagyris foetida & - & - & - & - & + & - & - & $\mathrm{Ph}$ & FS \\
\hline Calicotome villosa & - & - & + & + & - & + & - & $\mathrm{Ph}$ & FS \\
\hline Genista acanthoclada & + & - & + & + & + & + & + & $\mathrm{Ph}$ & FS \\
\hline Anthyllis hermanniae & - & + & + & + & + & + & + & $\mathrm{Ph}$ & FS \\
\hline Anthyllis vulneraria & - & - & - & + & - & - & - & $\mathrm{H}$ & OS \\
\hline Bituminaria bituminosa & - & + & - & - & - & - & - & $\mathrm{Ch}$ & os \\
\hline Dorycnium hirsutum & - & - & - & + & - & - & - & $\mathrm{Ch}$ & os \\
\hline Onobrychis ebenoides & & & - & + & - & - & - & $\mathrm{H}$ & OS \\
\hline Trifolium uniflorum & & & + & - & - & - & - & $\mathrm{H}$ & os \\
\hline Trifolium fragiferum & - & + & - & - & - & - & - & $\mathrm{H}$ & OS \\
\hline Trifolium campestre & + & + & + & + & - & + & + & $\mathrm{Th}$ & OS \\
\hline Trifolium arvense & + & + & + & - & - & - & - & $\mathrm{Th}$ & OS \\
\hline Trifolium stellatum & + & + & + & - & - & + & - & $\mathrm{Th}$ & OS \\
\hline Trifolium lappaceum & + & - & - & - & - & - & - & Th & OS \\
\hline Vicia villosa & - & + & - & - & - & - & - & Th & os \\
\hline Vicia tetrasperma & + & + & + & + & - & - & - & $\mathrm{Th}$ & OS \\
\hline Vicia sativa & + & - & & - & - & - & - & Th & OS \\
\hline Lathyrus setifolius & - & + & & - & - & - & - & $\mathrm{Th}$ & OS \\
\hline Lathyrus cicera & + & - & & - & - & - & - & Th & OS \\
\hline Lathyrus aphaca & + & + & & - & - & - & - & $\mathrm{Th}$ & os \\
\hline Ononis variegata & - & + & & - & - & - & - & $\mathrm{Th}$ & os \\
\hline Medicago arborea & - & - & & - & + & - & - & $\mathrm{Th}$ & OS \\
\hline Medicago lupulina & - & + & & - & - & - & - & $\mathrm{Th}$ & OS \\
\hline Medicago orbicularis & + & + & & - & - & - & - & $\mathrm{Th}$ & OS \\
\hline Medicago littoralis & + & - & & - & - & - & - & Th & os \\
\hline Medicago polymorpha & - & + & & - & - & - & - & Th & OS \\
\hline Medicago minima & + & - & & - & - & - & - & $\mathrm{Th}$ & OS \\
\hline Lotus ornithopodioides & + & + & & - & & - & - & Th & os \\
\hline Securigera securidaca & - & + & & - & & - & - & $\mathrm{Th}$ & OS \\
\hline Securigera cretica & - & + & & - & & - & - & $\mathrm{Th}$ & OS \\
\hline Hippocrepis unisiliquosa & + & + & & - & & - & - & $\mathrm{Th}$ & os \\
\hline Scorpiurus muricatus & + & + & & - & & - & - & $\mathrm{Th}$ & OS \\
\hline 9.GERANIACEAE & & & & & & & & & \\
\hline Geranium molle & - & + & & - & & + & + & Th & os \\
\hline Erodium malacoides & + & - & & - & & - & - & $\mathrm{Th}$ & OS \\
\hline
\end{tabular}


Table 2. Continued.

\begin{tabular}{|c|c|c|c|c|c|c|c|c|c|}
\hline \multirow[b]{2}{*}{ TAXA } & \multicolumn{7}{|c|}{ Post_Fire Years } & \multirow[b]{2}{*}{$\mathbf{L F}$} & \multirow[b]{2}{*}{$\mathbf{R M}$} \\
\hline & $\mathbf{I}$ & 2 & $\mathbf{3}$ & 4 & 11 & 15 & $>\mathbf{3 0}$ & & \\
\hline \multicolumn{10}{|l|}{ 10.LINACEAE } \\
\hline $\begin{array}{l}\text { Linum pubescens } \\
\text { 11.EUPHORBIACEAE }\end{array}$ & & & - & - & & - & - & Th & os \\
\hline $\begin{array}{l}\text { Euphorbia taurinensis } \\
\text { 12.ANACARDIACEAE }\end{array}$ & & & - & + & & - & - & Th & OS \\
\hline Pistacia lentiscus & + & + & + & + & & + & + & $\mathrm{Ph}$ & OR \\
\hline $\begin{array}{l}\text { Pistacia terebinthus } \\
\text { 13.MALVACEAE }\end{array}$ & + & + & - & - & + & - & - & $\mathrm{Ph}$ & $\mathrm{OR}$ \\
\hline $\begin{array}{l}\text { Malva sylvestris } \\
\text { 14.THYMELAEACEAE }\end{array}$ & & & + & - & + & + & + & $\mathrm{H}$ & OR \\
\hline $\begin{array}{l}\text { Thymelaea tartonraira } \\
\text { 15.HYPERICACEAE }\end{array}$ & & & - & + & - & - & - & $\mathrm{Ch}$ & FS \\
\hline $\begin{array}{l}\text { Hypericum empetrifolium } \\
\text { 16.CISTACEAE }\end{array}$ & & & + & + & + & + & + & $\mathrm{Ch}$ & FS \\
\hline Cistics creticus & + & + & - & + & + & - & + & $\mathrm{Ph}$ & os \\
\hline Cistus salvifolius & - & - & + & + & + & + & - & $\mathrm{Ph}$ & os \\
\hline Cistus monspeliensis & - & - & + & - & + & - & - & $\mathrm{Ph}$ & OS \\
\hline $\begin{array}{l}\text { Fumana thymilfolia } \\
\text { 17.UMBELLIFERAE }\end{array}$ & + & + & + & + & - & + & + & $\mathrm{Ch}$ & OS \\
\hline Tordyllium apulum & - & - & + & - & - & - & - & $\mathrm{Th}$ & $\operatorname{os}$ \\
\hline Scandix pecten-jacobeus & - & + & - & - & - & - & - & $\mathrm{Th}$ & OS \\
\hline $\begin{array}{l}\text { Daucus carota } \\
\text { 18.ERICACEAE }\end{array}$ & - & + & - & - & - & - & - & Th & os \\
\hline Arbutus unedo & + & - & - & - & + & - & - & $\mathrm{Ph}$ & OR? \\
\hline Arbutus andrachne & - & - & - & - & + & - & - & $\mathrm{Ph}$ & OR? \\
\hline Erica arborea & - & - & + & - & + & - & - & $\mathrm{Ph}$ & FS \\
\hline $\begin{array}{l}\text { Erica manipulfiora } \\
\text { 19.PRIMULACEAE }\end{array}$ & - & - & - & - & + & - & - & $\mathrm{Ph}$ & $\mathrm{FS}$ \\
\hline $\begin{array}{l}\text { Cyclamen graecum } \\
\text { 20.OLEACEAE }\end{array}$ & & & + & + & + & + & + & $\mathrm{G}$ & OR \\
\hline Olea europaea & - & + & - & + & + & + & + & $\mathrm{Ph}$ & OR \\
\hline $\begin{array}{l}\text { Phillyrea latifolia } \\
\text { 21.RUBLACEAE }\end{array}$ & - & + & + & + & + & - & + & $\mathrm{Ph}$ & OR \\
\hline Gallium aparine & - & + & - & - & - & - & - & $\mathrm{Th}$ & os \\
\hline $\begin{array}{l}\text { Rubia peregrina } \\
\text { 22.CONVOLVULACEAE }\end{array}$ & + & + & - & - & - & - & - & $\mathrm{H}$ & OR \\
\hline $\begin{array}{l}\text { Convolvulus elegantissimus } \\
\text { 23.BORAGINACEAE }\end{array}$ & & & + & + & - & + & + & $\mathrm{H}$ & OR \\
\hline $\begin{array}{l}\text { Alkanna tinctoria } \\
\text { 24,LABIATAE }\end{array}$ & & & - & - & - & + & + & $\mathrm{H}$ & OR \\
\hline Ajuga chamaepitus & + & - & - & - & - & - & - & $\mathrm{H}$ & QR? \\
\hline Teucrium sp. & - & - & - & + & - & + & + & $\mathrm{Ch}$ & OR? \\
\hline Prasiun majus & - & + & - & - & - & - & + & $\mathrm{Ch}$ & OR? \\
\hline Ballota acelabulosa & - & + & - & - & - & - & - & $\mathrm{H}$ & OR? \\
\hline Stachys sp. & - & + & - & - & + & + & + & $\mathrm{H}$ & OR? \\
\hline Satureja thymbra & - & - & + & + & + & + & - & $\mathrm{Ch}$ & FS? \\
\hline $\begin{array}{l}\text { Coridothymus capilatus } \\
\text { 25.SCROPHULARIACEAE }\end{array}$ & - & - & - & - & + & + & + & $\mathrm{Ch}$ & FS? \\
\hline $\begin{array}{l}\text { Veronica cymballaria } \\
\text { 26.GLOBULARIACEAE }\end{array}$ & + & + & - & - & - & - & - & $\mathrm{H}$ & FS? \\
\hline $\begin{array}{l}\text { Globularia alypum } \\
\text { 27.PLANTAGINACEAE }\end{array}$ & & & - & - & - & + & - & $\mathrm{CH}$ & OR \\
\hline $\begin{array}{l}\text { Plantago sp. } \\
\text { 28.CAPRIFOLIACEAE }\end{array}$ & & & + & - & - & & - & $\mathrm{H}$ & OR \\
\hline $\begin{array}{l}\text { Lonicera etrusca } \\
\text { 29.VALERIANELLACEAE }\end{array}$ & + & - & - & - & - & & - & $\mathrm{Ph}$ & OR \\
\hline $\begin{array}{l}\text { Valerianella sp. } \\
\text { 30.DIPSACACEAE }\end{array}$ & - & - & - & + & - & & - & Th & os \\
\hline $\begin{array}{l}\text { Lomelosia brachiata } \\
\text { 31.CAMPANULACEAE }\end{array}$ & - & + & + & + & - & & - & Th & OS \\
\hline Campanula drabiflora & - & + & - & & - & & - & Th & OS \\
\hline
\end{tabular}


Table 2. Continued.

\begin{tabular}{|c|c|c|c|c|c|c|c|c|c|}
\hline \multirow[b]{2}{*}{ TAXA } & \multicolumn{7}{|c|}{ Post-Fire Years } & \multirow[b]{2}{*}{ LF } & \multirow[b]{2}{*}{$\mathbf{R M}$} \\
\hline & 1 & 2 & 3 & 4 & 11 & 15 & $>\mathbf{3 0}$ & & \\
\hline \multicolumn{10}{|l|}{ 32. COMPOSITAE } \\
\hline Helichrysum sp. & - & - & - & + & - & - & - & $\mathrm{Ch}$ & OR? \\
\hline Phagnalon graecum & - & - & - & - & + & + & + & $\mathrm{Ch}$ & OR \\
\hline Anthemis chio & - & + & + & - & - & - & - & Th & os \\
\hline Senecio vulgaris & - & + & - & + & - & - & - & $\mathrm{Th}$ & OS \\
\hline Calendula arvensis & - & + & - & + & - & - & - & $\mathrm{Th}$ & os \\
\hline Carduus pyctocephalus & - & + & - & + & - & - & - & $\mathrm{Th}$ & OS \\
\hline Hypochoeris achyrophorus & - & + & + & + & - & + & + & $\mathrm{Th}$ & OS \\
\hline Atractylis cancellata & - & + & - & + & - & - & - & Th & os \\
\hline Centaurea raphanina & + & + & + & + & - & - & + & $\mathrm{H}$ & OR \\
\hline Tragopogon sp. & - & + & + & + & + & + & + & $\mathrm{H}$ & OR \\
\hline Scorzonera crocifolia & + & - & + & + & + & - & + & $\mathrm{H}$ & OR \\
\hline Reichardio picroides & + & + & - & + & + & + & + & $\mathrm{H}$ & OR \\
\hline $\begin{array}{l}\text { Ditrichia viscosa } \\
\text { 33,LILIACEAE }\end{array}$ & - & - & - & + & - & - & - & $\mathrm{Ch}$ & OR \\
\hline Asphodelus aestivus & - & - & + & + & - & + & + & G & OR \\
\hline Asphodeline Iutea & - & - & - & + & - & - & - & G & OR \\
\hline Gagea graeca & - & - & - & - & - & - & + & G & OR \\
\hline Scilla autumnalis & - & - & - & - & - & - & + & $\mathrm{G}$ & OR \\
\hline Ornithogallum divergens & - & + & - & - & - & - & - & G & OR \\
\hline Muscari commosum & + & + & + & + & - & + & + & $\mathrm{G}$ & $\mathrm{OR}$ \\
\hline Asparagus acutifolius & + & + & + & - & - & + & + & $\mathrm{Ch}$ & OR \\
\hline Ruscus aculeatus & - & + & - & - & - & - & - & $\mathrm{Ch}$ & OR \\
\hline $\begin{array}{l}\text { Smilax aspera } \\
\text { 34.IRIDACEAE }\end{array}$ & + & + & + & + & - & - & - & $\mathrm{Ph}$ & OR \\
\hline Crocus cartwrightianus & - & + & + & + & + & + & + & $\mathrm{G}$ & OR \\
\hline Romulea sp. & - & - & - & - & - & + & - & $\mathrm{G}$ & OR \\
\hline $\begin{array}{l}\text { Gladiolus sp. } \\
\text { 35.GRAMINEAE }\end{array}$ & + & - & - & - & - & - & - & $\mathrm{G}$ & $\mathrm{OR}$ \\
\hline Cynosturus echinatus & + & - & - & - & - & - & - & $\mathrm{Th}$ & os \\
\hline Briza maxima & - & + & - & - & - & - & - & Th & os \\
\hline Aegilops geniculata & - & - & - & + & + & - & - & $\mathrm{Th}$ & os \\
\hline Lagurus ovatus & - & + & - & + & + & + & - & $\mathrm{Th}$ & os \\
\hline Bromus ramosus & - & + & + & + & - & - & - & $\mathrm{Th}$ & os \\
\hline Avena sterilis & - & - & - & + & - & - & - & $\mathrm{Th}$ & os \\
\hline $\begin{array}{l}\text { Brachypodium syluaticum } \\
\text { 36.ARACEAE }\end{array}$ & + & + & + & + & + & + & + & $\mathrm{H}$ & OR \\
\hline $\begin{array}{l}\text { Arisarum vulgare } \\
\text { 37.ORCHIDACEAE }\end{array}$ & & & & & & & & G & OR \\
\hline Ophrys lused & & & & & & & & $\mathrm{G}$ & OR \\
\hline Serapias sp. & & & & & & & & $\mathrm{G}$ & OR \\
\hline
\end{tabular}

tool that allows us to predict the post-fire behaviour of a plant according to its life form (Chapman and Crow 1981). Of course in many cases things might not be so simple. For example, phanerophytes in general are regarded as resprouters but Pinus halepensis and Cistus spp. are obligate seeders. Chamaephytes and hemicryptophytes also seem to exhibit a diverse post-fire behaviour. For hemicryptophytes, in particular, it seems that post-fire behaviour is more or less a characteristic depending on the family in which the taxon belongs. For example all the hemicryptophytes of the Compositae recorded are resprouters (Table 2). On the other hand, it is known that the hemicryptophytes of the Leguminosae that colonise the burned pine forests are seeders (Papavassiliou and Arianoutsou 1993). Finally, therophytes are obligate seeders, and geophytes seem to be obligate resprouters.
In the early post-fire years, herbaceous flora dominated Aleppo pine forests, as is true for other Mediterranean climate ecosystems (Hanes 1971, Naveh 1973, Trabaud 1980, Arianoutsou-Faraggitaki and Margaris 1981a, Arianoutsou- Faraggitaki 1984, De Lillis and Testi 1992, Keeley 1992, Faraco et al 1993). The majority of those taxa were restricted only to the first few years after fire and they were obligate seeders. Their seeds, which remain viable for many years and form soil seed bank, germinate primarily after fire (Keeley and Zedler 1978, Arianoutsou and Margaris 1981b, Papavassiliou et al 1994). An exception to this general trend seem to be South African fynbos, where the post-fire flora is dominated by geophytes (Kruger 1983). Part of the explanation is that bulbs and corms are an efficient nutrient pool (Le Maitre and Migley 1992), which is so cricial for the nutrient poor 


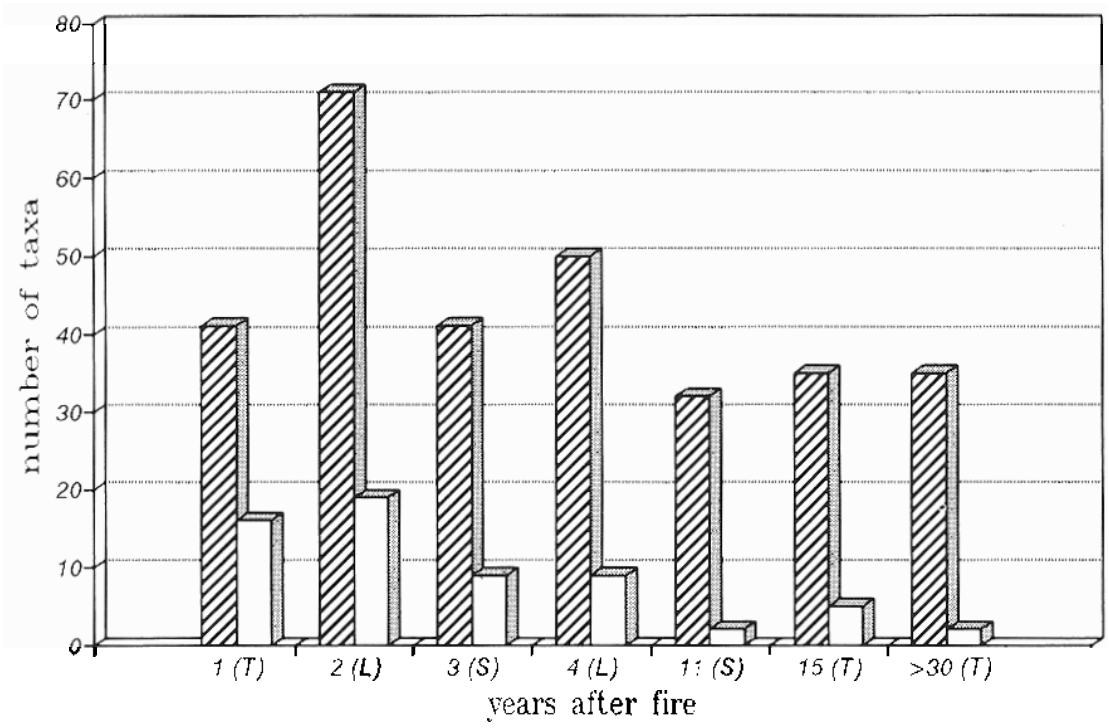

\section{WIIt all taxa $\square$ legumes}

Figure 1. Total species richness and richness of leguminous taxa at each study site ( $T$ : tertiary deposits, L: limestones, $S$ : schists).

fynbos soils. Another reason could be fire intervals. In the Mediterranean Basin and in California there are longer fire intervals as compared to those in South Africa (cited by Keeley 1992). These relatively long fire intervals $(>40$ years) may favour the formation of seed banks as a rather efficient mode of survival. In other words, the annual habit may be more compatible with longer, unpredictable firefree periods (Keeley 1992). In fynbos, geophytes can persist for many more years after fire due to the more open nature of the vegetation (Kruger 1983). Finally, the greater summer water stress faced by the Mediterranean and Californian systems (cited by Keeley 1992) may make survival of perennials less favourable in post-fire environments. This evidence is supported by the fact that in arid fynbos annuals become more important (Kruger 1979).

The highest increase in species richness occurs in the second post-fire year. This increase cannot be attributed to the enrichment of the flora of the burned forest by dor-

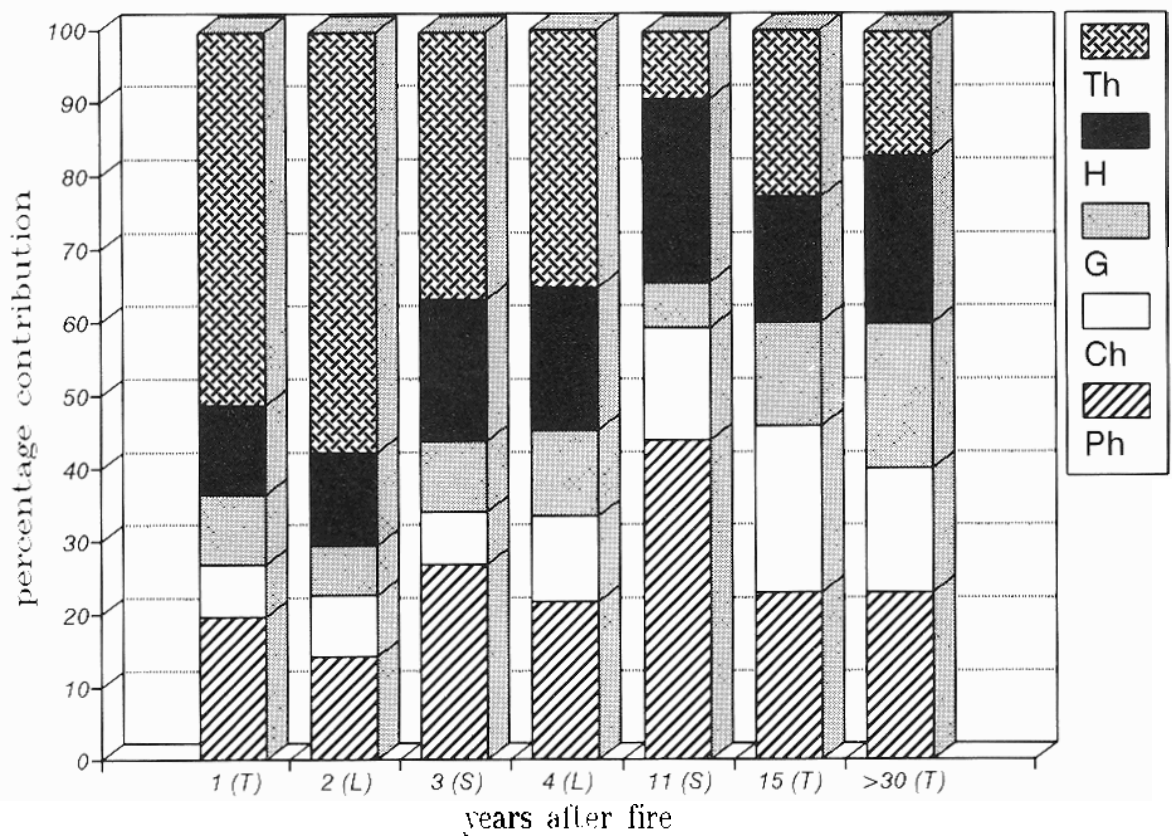

Figure 2. Percentage contribution of each life form to the flora of the study sites (T: tertiary deposits, L: limestones, S: schists). 
Table 3. Regeneration mode (RM) and life forms in the recorded plant taxa.

\begin{tabular}{lccccc}
\hline & \multicolumn{5}{c}{ PLANT LIFE FORMS } \\
\cline { 2 - 6 } REGENERATION MODE & $\mathrm{Ph}$ & $\mathrm{Ch}$ & $\mathrm{G}$ & $\mathrm{H}$ & $\mathrm{Th}$ \\
\hline obligate seeders & 50.0 & 56.0 & 0.0 & 68.0 & 100.0 \\
obligate resprouters & 23.0 & 19.0 & 100.0 & 21.0 & 0.0 \\
faculative seeders & 27.0 & 25.0 & 0.0 & 11.0 & 0.0 \\
\hline
\end{tabular}

mant seeds, since it is expected that all of the hard-coated seeds have already germinated in the first year. Data from other Mediterranean countries support our results on the increase of floristic richness early after fire. Trabaud and Lepart (1980) mention that floristic richness of Pinus halepensis woodlands, Rosmarinus officinalis garrigues, Quercus ilex coppices and Quercus coccifera garrigues grows gradually to reach a maximum between the 10 th and the 40 th month. Then the floristic richness diminishes. Finally, a relative stabilisation occurs from the 60 th month onwards. Similarly, after the second post-fire year they noted a decrease in the number of taxa of the Aleppo pine forests, which was mainly due to the loss of the therophytes.

The presence of the therophytes in the early post-fire stages and their subsequent relative absence from the latter stages may be related to their germination mechanisms. Most of the species which appear immediately after fire have seeds whose germination is directly or indirectly induced by fire. The direct induction is mediated through the mechanical eruption of the hard seed coat caused by soil heating. This mechanism has been proved for many woody and herbaceous plants with hard seed coats (Arianoutsou and Margaris 1981b, Keeley 1991, Roy and Sonie 1992, Thanos et al 1992, Keeley 1992). Indirect induction of seed germination can be related to the re-

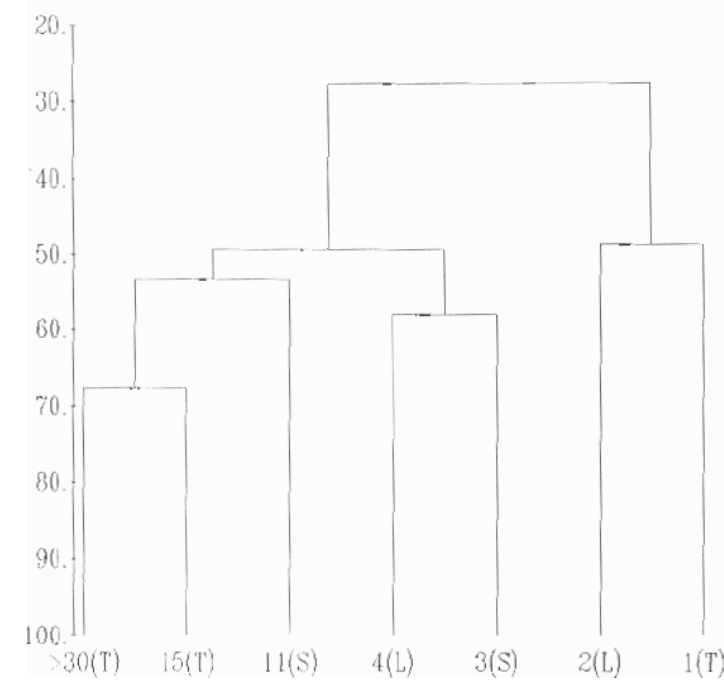

Figure 3. Patterns of Bray-Curtis similarity between clusters of plant taxa (T: tertiary deposits, L.: limestones, S: schists). moval of the canopy (Roy and Arianoutsou-Faraggitaki 1985). Once a fire consumes the vegetation, the incident light coming to the soil surface has a different spectrum, since there is no leafy filter to intercept it. This leads to a change in the Red:Far Red ratio which reaches the light sensitive seeds, which therefore germinate. It is possible that some of the soft-coated seeds are induced to germinate this way. We assume that further decrease in the herbaceous taxa which is observed in the morc mature stands ( $3 \mathrm{yr}$ old burn and onwards) is due to the restriction imposed by the competition for light and nutrients with the woody species which costantly occupy more space.

Although we expected that the species richness would decrease with increasing stand age, we found that in Fyli (4 yr-old burn site) the flora was richer than that of Stamata ( 3 yr-old burn site). This difference may have resulted from a thick layer of bryophytes at Stamata that may have negatively affected the plant community. In the 11-year stand woody species dominated the ecosystem. The vegetation was quite dense and the herbaceous cover was limited. Finally, in the 15-year stand the vegetation appeared less dense; the canopy opened slightly again and some herbaceous species reappeared.

The richest plant family in terms of taxa during the first years of the post-fire chronosequense was Leguminosac. This has also been reported by other researchers (Martin 1966, Hanes 1971, Naveh 1973, Chen et al 1975, Arianoutsou 1979, Rundel 1981, Westman 1981, Van Wilgen 1981, Thanos et al 1989, Papavassiliou and Arianoutsou 1993, Cocks 1994) for Mediterranean climate ecosystems. For example, Martin (1966) reported a $245 \%$ increase in the density of Leguminosae genera Amphithalea, Indigofera, Bituminaria (ex Psoralea) and Tephrosia in a one-year old burned area of fynbos. Van Wilgen and Kruger (1981) observed a mean cover of 4.5 and $3.3 \%$ of Rafnia capensis for two four-year old sites; this species was absent from the nearby mature (21 and 35 ycars) stands. Westman (1981) working in California coastal sage scrubs reported a drop in cover of five legume species (three species of Lupinus and two species of Lotus) from $11.5 \%$ to $1.5 \%$ between the first and the seventh year after fire. After 21 years, legume cover had decreased to almost zero. Arianoutsou (1995) reported that taxa of Leguminosae consisted up to $77 \%$ of the above ground plant biomass in a 3-year burned pine forest in Attica, Greece. Plants of this family are particularly important because they are able to form symbiotic relations 
with nitrogen-fixing soil bacteria, thus contributing to nitrogen enrichment of the soil (Rundel 1981, ArianoutsouFaraggitaki and Margaris 1981a, c, Papavassiliou and Arianoutsou 1993; Arianoutsou and Thanos 1994, Cocks 1994).

The vast majority of the species in the first years after fire were herbaceous and their presence was restricted to the first post-fire stages. Only three woody species were recorded: Calicotome villosa, Genista acanthoclada and Anthyllis hermanniae.

It is known that Leguminosae can grow over a wide range of geological substrates (Antonovics et al 1971, Proctor and Woodell 1975). It is this wide preference that may explain the way the studied sites are grouped in the cluster analysis performed. The sites are clustered according to their post-fire stage and not according to the bedrock formation underlying them, as long as legumes are the main component dominating in the flora of the sites. On the three older sites data suggest a tendency for sites to be grouped according to substrate. However, more research is needed for the strong justification of this aspect.

Other families with a high number of taxa were those of Compositae and Gramineae. They were most important on the 4-yr-old site.

Our results show that post-fire succession at the Allepo pine forests of Attica is similar to the succession of other Meditteranean ecosystems (Arianoutsou-Faraggitaki 1984, Espirito-Santo et al 1993, Lucchesi and Giovannini 1993, Ne'eman et al 1993 among others). Still, there are not enough data in the Meditteranean region, to develop a strong theory of species replacement during post-fire succession, primarily because it has been difficult to obtain long-term diachronic data on the same permanent plots in these human- disturbed areas. Many researchers use the synchronic method, which has the shortcoming arising from the difficulty in identifying sites which are different only in their post-fire age. It is our aim to contribute towards the filling of this gap by a combination of both methods under the framework of an ongoing project.

Acknowledgements. Financial support given by the Greek Ministry of Industry, Energy and Technology, General Secretariat for Research and Technology (PENED 91 ED 944 Project) and the European Union (EV5V-CT94-0482 project, ENVIRONMENT programme) are gratefully acknowledged.

\section{References}

Antonovics, J., A.D. Bradshaw and R.G. Turner. 1971. Heavy metal tolerance in plants. Advances in Ecological Research 7 : 1.85 .

Arianoutsou, M. 1979. Biological activity after fire in a phryganic ecosystem. Ph.D. Thesis, in Greek with an English summary.
Arianoutsou-Faraggitaki, M. and N.S. Margaris. 1981a. Producers and the fire cycle in a phryganic ecosystem. In: Components of productivity of Mediterranean-climate regions: basic and applied aspects. (edited by N.S. Margaris and H.A. Mooney). Dr W. Junk Publishers, The Hague, Boston, London, pages 181-190.

Arianoutsou, M. and N.S. Margaris. 1981b. Early stages of succession after fire in a phryganic (East Mediterranean) ecosystem. I. Regeneration by seed germination. Biologie Ecologie Mediterraneenne 8:119-128.

Arianoutsou, M. and N.S. Margaris. 1981c. Fire-induced nutrient losses in a phryganic ecosystem. International Journal of Biometeorology 25:341-347.

Arianoutsou-Faraggitaki, M. 1984, Post-fire successional recovery of a phryganic (East Mediterranean) ecosystem. Acta Oecologica (Oecologia Plantarum) 59:387-394.

Arianoutsou, M. and C.A. Thanos. 1994. Legumes in the fireprone Mediteranean environment. In: Book of Proceedings of the 2nd International Conference of Forest Fire Research, Coimbra, Portugal, (edited by D.X. Viegas), Vol. II, pages 995-1005.

Arianoutsou, M. 1995. Legume Post-Fire Flora and its Contribution in the Regeneration of Mediterranean Ecosystems after Fire. Project 91 ED 944 Final Report, General Secretariat of Research and Technology (in Greek), 101 pages.

Brower, J.E., J.H. Zar and C.N. von Ende. 1990. Field and Laboratory Methods for General Ecology. Wm. C. Brown Publishers, Dubuque, pages 87-92 and 172-174.

Chapman, R.R. and G.E. Crow. 1981. Application of Raunkiaer's life form system to plant species survival after fire. Bulletin of the Torrey Botanical Club 108:472-478.

Chen, M., E.J. Hodgkins and W.J. Watson. 1975. Prescribed burning for improving pine production and wildlife habitat in the hilly coastal plain of Alabama. Alabama Agricultural Experimental Station Bulletin 473: 19.

Clarke, K.R. and R.M. Warwick. 1994. Change in Marine Communities: An Approach to Statistical Analysis and Interpretation. Natural Environment Research Council, UK, 144 pages.

Cocks, M. 1994. The ecology and nitrogen-fixing ability of selected Aspalathus spp. in fyrbos ecosystems. MSc. Thesis, University of Cape Town, Department of Botany, 161 pages.

De Lillis, M. and A. Testi. 1992. Fire disturbance and vegetation dynamics in a mediterr anean maquis of central Italy. Ecologia Mediterranea XVIII: 55-68.

Espirito-Santo M. D., F. Rego and J.C. Costa. 1993. Vegetation dynamics in the Serra dos Canderros (Central Portugal). In: Fire in Mediterranean Ecosystems (edited by L. Trabaud and R. Prodon), Ecosystem Research Report no 5, Commission of the European Communities, Brussels - Luxembourg, pages 29-46.

Faraco, A.M., F. Femandez and J.M. Moreno. 1993. Post-fire vegetation dynamies of pine woodlands and shrubl ands in the Siena De Gredos, Spain. In: Fire in Muliteranean Ecosystems (edited by L. Trabaud and R. Prodon), Ecosystem Research Report no 5, Commission of the European Communities, Brussels - Luxembourg, pages 101-112.

Greuter, W., H.M. Burdet and G. Long (editots). 1984, 1986, 1989. Med-Checklist 1, 3, 4. Geneve.

Hanes, T.L. 1971. Succession after fire in the chaparral of Southem Califomia. Ecological Monographs 41: 27-52. 
Le Maitre, D.C. and J.J. Midgley. 1992. Plant reproductive ecology. In: The Ecology of Fynbos. Nutrients, Fire and Diversity (edited by R. Cowling), Oxford University Press, Cape Town, pages 135-175.

Kailidis. D.S. 1992. Forest fires in Greece. In: Book of Proceedings of the International Seminar on Forest Fire Prevention, Land Use and People. Greek Ministry of Agriculture, Secretariat General for Forests and Natural Environment, Athens, pages $27-40$.

Keeley, J.E. and P.H. Zedler. 1978. Reproduction of chaparral shrubs after fire: a comparison of sprouting and seeding strategies. American Midland Naturalist 99: 142-161.

Keeley, J.E. 1991. Seed germination and life history syndromes in the California chaparral. Botanical Review 57: 81-116.

Keeley, J.E. 1992. A Califomian's view of fynbos. In: The Ecology of Fynbos. Nutrients, Fire and Diversity (edited by R. Cowling), Oxford University Press, Cape Town, pages 372-389.

Kruger, F.J. 1979. South African Heathlands. In: Heathlands and Related Shrublands (edited by R.L. Specht), Elsevier, New York, pages 19-80.

Kruger, F.J. 1983. Plant community diversity and dynamics in relation to fire. In: Mediterranean-type ecosystems: the role of nutrients (edited by F.J. Kruger, D.T. Mitchell and J.U.M. Jarvis), Springer-Verlag, New York, pages 446-472.

Lucchesi, S. and G. Giovannini. 1993. Plant community dynamics following fire: a case study in Toscany. In: Fire in Mediterranean Ecosystems (edited by L. Trabaud and R. Prodon), Ecosystem Research Report no 5, Commission of the European Communities, Brussels - Luxembourg, pages 119-127.

Martin. A.R.H, 1966. The plant ecology of the Grahamsown Nature Reserve: II. Some effects of buming. Journal of South African Botany 32: 1-39.

Ministry of Agriculture 1992. Results of the First Forest Survey. General Secretariat of Forests and Natural Environment, 134 pages (in Greek).

Naveh, Z. 1967. Mediterr anean ecosystems and vegetation types in California and Israel. Ecology 48: 445-459.

Naveh, Z. 1973. The ecology of fire in Israel. Proceedings of the 13 th Annual Tall Timbers Fire Ecological Conference, pages 131-170.

Ne'eman, G., H. Lahav and I. Izhaki. 1993. The resilience of vegetation to fire in an East- Mediterranean pine forest on Mount Carmel, Israel: the effect of post-fire management. In: Fire in Mediterranean Ecosystems (edited by L. Trabaud and R.Prodon), Ecosystem Research Report no 5, Commission of the European Communities, Brussels - Luxembourg, pages 119-127.

Papavassiliou, S. and M. Arianoutsou. 1993. Regeneration of the Leguminous herbaceous vegetation following fire in a $P$ inus halepensis forest of Attica, Greece. In: Fire in Mediterranean Ecosystems (edited by L. Trabaud and R. Prodon), Ecosystem Research Report no 5, Commission of the European Communities,Brussels - Luxembourg, pages 119-127.

Papavassiliou, S., M. Arianoutsou and C.A. Thanos. 1994. Aspects of the reproductive biology of fire following species of leguminosae in a Pinus halepensis Mill, forest. In: Book of Proceedings of the 2nd International Conference of Forest Fire Research, Coimbra, Portugal, (edited by D.X. Viegas), Supplement.
Proctor, J. and S.R.J. Woodell. 1975. The ecology of serpentine soils. Advances in Ecological Research 9: 255-364.

Raunkiaer, C. 1934. The Life Forms of Plants and Statistical Plant Geography. Clarendon Press, Oxford.

Roy, J. and M. Arianoutsou-Faraggitaki. 1985. Light quality as the environmental trigger for the gemination of the post-fire species Sarcopoterium spinosum L. Flora 177: 345-349.

Roy, J. and L. Sonie. 1992. Germination and population dynamics of Cistus species in relation to fire. Joumal of Applied Ecology 29: 647-655.

Rundel, P.W. 1981. Fire as an Ecological Factor. In: Physiological Plant Ecology I, Springer-Verlag, Berlin, Heidelberg. New York, pages 501-538.

Thanos, C.A., S.Marcou, D. Christodoulakis and A. Yannitsaros. 1989. Early post-fire regeneration in Pinus brutia forest ecosystem of Samos island (Greece). Acta OEcologica 10: 79-94.

Thanos, C.A., K. Georghiou, C. Kadis and C. Pantazi. 1992. Cistaceae: a plant family with hard seeds. Israel Journal of Botany 41: 251-263.

Trabaud, L. and J. Lepart. 1980. Diversity and stability in garrigues ecosystems after fire. Vegetatio 43: 49-57.

Tutin, T.G., V.H. Heywood, N.A. Burges, D.M.Moore, S.M. Walters, D.H. Valentine and D.A. Webb. 1964-1980, Flora Europaea. Cambridge University Press, Cambridge.

Van Wilgen, B.W. and F.J. Kuger. 1981. Observations on the effects of fire on mountain fynbos at Zachariashoek, Paarl. Journal of South African Botany 47: 195-212.

Westman, W.E. 1981. Diversity relations and succession in California sage scrub. Ecology 62: 170-184. 